\title{
1 Vitamin D deficiency as risk factor for severe COVID-19: a convergence of two pandemics
}

2

3

4 De Smet D. (MD) ${ }^{1}$, De Smet K. (MD) ${ }^{2}$, Herroelen P. (MSc. $)^{1}$, Gryspeerdt S. (MD) ${ }^{2}$ and Martens G.A.

$5(\mathrm{MD}, \mathrm{PhD})^{1,3}$

$6{ }^{1}$ AZ Delta Medical Laboratories and ${ }^{2}$ Department of Radiology, AZ Delta General Hospital, Roeselare,

7 Belgium ${ }^{3}$ VUB Metabolomics Platform, Brussels Free University

8

9 Corresponding author: Geert A. Martens, AZ Delta Medical Laboratories, AZ Delta General Hospital,

Email: geert.martens@azdelta.be

Word count body: 2365

Word count abstract: 249

Revised version 2, May 15, 2020 
medRxiv preprint doi: https://doi.org/10.1101/2020.05.01.20079376; this version posted May 19, 2020. The copyright holder for this preprint (which was not certified by peer review) is the author/funder, who has granted medRxiv a license to display the preprint in perpetuity.

\author{
It is made available under a CC-BY-NC-ND 4.0 International license.
}

27 


\section{SUMMARY BOX}

\section{What is already known on this topic}

30 Vitamin D deficiency increases the incidence and severity of respiratory viral infections by

31 exacerbation of pro-inflammatory immune responses. Lung damage in COVID-19 involves excessive

32 inflammation and cytokine release. With more than 1 billion people worldwide affected by vitamin D

33 deficiency the world might now face a convergence of two pandemics. Data are emerging that

34 variations in vitamin D deficiency rates across ethnic and demographic subgroups are correlated to

35 severity of SARS-CoV-2 infections.

\section{What this study adds}

38 Our data reveal that more than $40 \%$ of the adult population in a wealthy European country is vitamin

COVID-19 pneumonia and predisposes to more advanced radiological disease stages. Specifically, men were at risk. This correlation was not confounded by vitamin D-impacted morbidities such as coronary artery disease, diabetes and chronic lung disease. Our findings support a causal relation between vitamin D deficiency and severe COVID-19 and call for vitamin D supplementation as safe, widely available and inexpensive mitigation strategy. 
medRxiv preprint doi: https://doi.org/10.1101/2020.05.01.20079376; this version posted May 19, 2020. The copyright holder for this preprint

(which was not certified by peer review) is the author/funder, who has granted medRxiv a license to display the preprint in perpetuity.

It is made available under a CC-BY-NC-ND 4.0 International license .

\section{Structured abstract}

49 Context. Through its immunological functions, vitamin D attenuates inflammatory responses to

50 respiratory viruses. Vitamin D deficiency might be a highly prevalent risk factor for severe SARS-CoV-

512 infections.

52 Objective. To investigate the level of vitamin D deficiency in West Flanders, Belgium and its

53 correlation to severity of COVID-19 as staged by CT

54 Design. Retrospective observational study

55 Setting. Central network hospital

56 Participants. 186 SARS-CoV-2-infected patients hospitalized from March 1, 2020 to April 7, 2020

57 Main outcome measure. Analysis of 25(OH)D in COVID-19 patients versus season/age/sex-matched diseased controls

Results. The rate of vitamin D deficiency $(25(\mathrm{OH}) \mathrm{D}<20 \mathrm{ng} / \mathrm{mL})$ in West Flanders varies with age, sex and season but is overall very high (39.9\%) based on analysis of 16274 control samples. We measured 25(OH)D levels in 186 COVID-19 patients (109 males (median age 68 years, IQR 53-79) and 77 females (median age 71 years, IQR 65-74)) and 2717 age/season-matched controls (999 males (median age 69 years, IQR 53-81) and 1718 females (median age 68 years, IQR 43-83)). COVID-19 patients showed lower median 25(OH)D (18.6 ng/mL, IQR 12.6-25.3, versus $21.5 \mathrm{ng} / \mathrm{mL}$, IQR 13.930.8; $\mathrm{P}=0.0016$ ) and higher vitamin $\mathrm{D}$ deficiency rates ( $58.6 \%$ versus $45.2 \%, \mathrm{P}=0.0005$ ). Surprisingly, this difference was restricted to male COVID-19 patients who had markedly higher deficiency rates

67 than male controls $(67.0 \%$ versus $49.2 \%, \mathrm{P}=0.0006)$ that increased with advancing radiological stage

68 and were not confounded vitamin D-impacted comorbidities.

69 Conclusions: vitamin D deficiency is a prevalent risk factor for severe COVID-19. Vitamin D supplementation might be an inexpensive and safe mitigation for the SARS-CoV-2 pandemic. 
medRxiv preprint doi: https://doi.org/10.1101/2020.05.01.20079376; this version posted May 19, 2020. The copyright holder for this preprint (which was not certified by peer review) is the author/funder, who has granted medRxiv a license to display the preprint in perpetuity.

It is made available under a CC-BY-NC-ND 4.0 International license .

\section{Introduction}

73 In severe SARS-CoV-2 infections excessive activity of pro-inflammatory immune cells contributes to 74 alveolar and endothelial damage triggering a vicious cycle that evolves towards severe COVID-19 ${ }^{1,2}$. 75 Beside its role in calcium metabolism, 1,25-dihydroxyvitamin $\mathrm{D}(25(\mathrm{OH}) \mathrm{D})$ is a pleiotropic regulator of

76 the immune system ${ }^{3,4}$. It stimulates the expression of cathelicidins and beta-defensin in respiratory 77 epithelia as barrier to pathogen invasion ${ }^{5,6}$. It acts as a pro-tolerogenic cytokine dampening excessive inflammation by inhibiting neutrophils and switching Th1 CD4 T cells and M1-polarized macrophages towards a type II immunity. Vitamin D deficiency increases the severity of respiratory virus infections 7,8 and contributes to variations in their incidence across seasons, age groups, socioeconomic status and geographies. Data are emerging that vitamin D deficiency is more prevalent in patients with severe COVID-19 pneumonia requiring intensive care ${ }^{9}$. More than a billion people worldwide are vitamin $D$ deficient ${ }^{10}$ with variations between sexes, ethnicities, social groups and geographies that appear to correlate with differences in incidence and outcome of COVID-19 lung disease based on modeling of large data sets ${ }^{11-13}$. Here we provide a first field validation of these models. We provide a detailed view on the surprisingly high prevalence of vitamin D deficiency

87 in a wealthy European region, the province of West Flanders, Belgium. We investigated the correlation of serum 25-hydroxyvitamin $\mathrm{D}(25(\mathrm{OH}) \mathrm{D})$ level to the risk to be hospitalized for severe COVID-19 pneumonia, the radiological disease stage as proxy for immunological stage and its possible confounding by vitamin D-impacted comorbidities, in cohort of 186 consecutive patients hospitalized for severe SARS-CoV-2 infection in a large Belgian network hospital.

92

Methods

94 Patients This is a retrospective observational study on 186 consecutive patients hospitalized from 95 March 1, 2020 to April 7,2020 for COVID-19 pneumonia at AZ Delta General Hospital in Roeselare, 96 Belgium (demographics in Table 2). 25(OH)D levels in COVID-19 patients were compared to an age97 and season-matched diseased control population, consisting of 2717 consecutive unselected patients 
medRxiv preprint doi: https://doi.org/10.1101/2020.05.01.20079376; this version posted May 19, 2020. The copyright holder for this preprint (which was not certified by peer review) is the author/funder, who has granted medRxiv a license to display the preprint in perpetuity.

It is made available under a CC-BY-NC-ND 4.0 International license .

98

99

100

101

102

103

104

105

106

107

108

109

110

111

112

113

114

115

116

117

118

119

120

121

122

123

sampled from March 1, 2019 to April 30, 2019. The prevalence and age/sex/seasonal-distribution of vitamin D status in the general population was derived from all 25(OH)D measurements from January 1, 2019 to December 31, 2019 on 16274 consecutive, unselected and unique patient samples (Table 1). This study was approved by the AZ Delta ethical committee (Clinical Trial Number IRB B1172020000009) with a waiver of informed consent from study participants considering the study is based on secondary analysis of existing data.

Procedures: Chest CT On admission all COVID-19 patients received a chest CT (detailed CT scanning protocol in Supplementary Information) to determine the disease stage by consensus evaluation of the predominant radiological presentation: ground-glass opacities (early stage, 0-4 days, "stage 1"), crazy paving pattern (progressive stage, 5-8 days, "stage 2"), (3) consolidation (peak stage, 10-13 days, "stage 3 ") ${ }^{14}$. Analysis of comorbidities: prevalence of diabetes was registered by anamnesis and review of electronic patient records. Chronic lung disease (emphysema, fibrosis, bronchiectasis) and coronary artery disease (coronary artery calcification scoring) were objectified by chest CT. Laboratory analyses: all serum 25(OH)D measurements in this study were done in a central lab by the exact same method using Elecsys $®$ vitamin D total II (Roche, Switzerland) traced to the official reference ID-LC-MS/MS (Ghent University). SARS-CoV-2 infection was confirmed in all COVID-19 patients by PCR for E/N/RdRP genes (Allplex ${ }^{\mathrm{TM}}$ 2019-nCoV assay, Seegene, Seoul, Korea) on nasopharyngeal swabs.

Statistical analysis Data (not normally distributed) are expressed as medians (IQR) and MannWhitney test was used to test statistical differences between groups. Proportions for categorical variables were compared using chi-squared test. Spearman's rank correlation was used to identify correlations between 25(OH)D and comorbidities as confounding factors $\left(r_{s}, 95 \% \mathrm{Cl}\right)$. Statistical analyses were performed using MedCalc (version 12.2.1, Mariakerke, Belgium) and considered significant if $P$ value was less than .05 . 
medRxiv preprint doi: https://doi.org/10.1101/2020.05.01.20079376; this version posted May 19, 2020. The copyright holder for this preprint (which was not certified by peer review) is the author/funder, who has granted medRxiv a license to display the preprint in perpetuity.

It is made available under a CC-BY-NC-ND 4.0 International license .

\section{Results}

Epidemiology and distribution of vitamin D deficiency in the general population The prevalence and distribution of vitamin D deficiency the general population in the province of West Flanders, Belgium, was derived from 25(OH)D measurements in 16274 consecutive, unselected and unique patient sampled from January 1, 2019 to December 31, 2019. Table 1 summarizes the demographics and distributions according to sex, age and season and lists relevant statistical differences. Males had lower median 25(OH)D than females $(22.3 \mathrm{ng} / \mathrm{mL}$, IQR $14.9-31.3$ versus $23.7 \mathrm{ng} / \mathrm{mL}$, IQR 15.6-33.1, $\mathrm{P}<0.0001)$ and higher rates of vitamin $\mathrm{D}$ deficiency $(42.0 \%$ versus $38.6 \%, \mathrm{P}<0.0001)$ (Fig. $1 \mathrm{~A})$. With the exception of the very young ( $<10$ years), vitamin D deficiency was endemic in all age groups (Fig. 1B, Table 1). Men and women above 18 years showed lower median 25(OH)D levels and higher vitamin $D$ deficiency rates than individuals of 18 years or younger $(\mathrm{P}<0.05)$. As expected, $25(\mathrm{OH}) \mathrm{D}$ $25(\mathrm{OH}) \mathrm{D}$ levels and highest rates of vitamin $\mathrm{D}$ deficiency, with men (48.6\%) markedly more affected than females $(42.5 \%, \mathrm{P}<0.05)$.

144 CoV-2 infection were admitted to the hospital from March 1, 2020 to April 7,2020 for COVID-19 145 pneumonia: 109 males (median age 68 years, IQR 53-79 years) and 77 females (median age 71 years, 146 IQR 65-74 years). 25(OH)D in COVID-19 patients was compared a control group of 2717 patients with 147 similar age distribution, sampled in March and April, 2019. COVID-19 patients had an even lower 148 median $25(\mathrm{OH}) \mathrm{D}$ on admission $(18.6 \mathrm{ng} / \mathrm{mL}$, IQR $12.6-25.3)$ than controls $(21.5 \mathrm{ng} / \mathrm{mL}, \mathrm{IQR}$ 13.9-20.8, $149 \mathrm{P}=0.0016)$ and a markedly higher percentage of vitamin $\mathrm{D}$ deficiency ( defined as 25(OH)D < 
medRxiv preprint doi: https://doi.org/10.1101/2020.05.01.20079376; this version posted May 19, 2020. The copyright holder for this preprint (which was not certified by peer review) is the author/funder, who has granted medRxiv a license to display the preprint in perpetuity.

It is made available under a CC-BY-NC-ND 4.0 International license .

$15020 \mathrm{ng} / \mathrm{mL}$ ): $58.6 \%$ versus $45.2 \%(P=0.0005)$ (Table 2 ). Considering the male preponderance in COVID-

15119 patients (59\%) but underrepresentation in controls (37\%), we then stratified 25(OH)D for sex

152 (Fig.2A-C and Table 2). Remarkably, we observed a sexual dimorphism. Female COVID-19 patients

153 were not more vitamin $\mathrm{D}$ deficient than female controls (46.8\% versus $42.8 \%, \mathrm{P}=0.5646$, Fig.2B).

154 Control males showed higher vitamin D deficiency rates than control females $(49.2 \%$ versus $42.8 \%$,

$155 \mathrm{P}<0.0001$ Fig.2A). In male COVID-19 patients, vitamin D deficiency was even more profound (Fig.2C),

156 with lower median 25(OH)D (17.6 ng/mL, IQR $12.7-24.0$ versus $20.3 \mathrm{ng} / \mathrm{mL}$, IQR $13.7-28.3, \mathrm{P}=0.0234)$

157 and a markedly higher deficiency rate $(67.0 \%$ versus $49.2 \%, P=0.0006)$ than male controls.

158

159

Correlation between vitamin D status and disease stage Patients were screened by CT to determine

160

the temporal phase of COVID-19 lung disease and classified based on the predominant radiological

161

lesion (Fig.2D-F) as early stage 1 (ground-glass opacities), progressive stage 2 (crazy paving pattern)

162

or peak stage 3 (consolidation). These stages are considered as proxy for the immunological phase of

163

COVID-19 with an early phase of active viral replication in lower airways (stage 1), progressive

164

recruitment of pro-inflammatory cells to the lung interstitial space (stage 2), ending in diffuse

165

alveolar damage and fibrosis (stage 3). $24.7 \%, 29.6 \%$ and $45.7 \%$ of patients presented in stage 1,2

166

and 3, respectively with similar distribution in males and females (Table 2). Analysis of 25(OH)D

167

across radiological disease stages (Fig.2G-H, Table 2) strengthened the correlation: male COVID-19

168

patients showed progressively lower median 25(OH)D with advancing stage, resulting in vitamin D

169

deficiency rates increasing from $55.2 \%$ in stage $1,66.7 \%$ in stage 2 to $74.0 \%$ in stage $3(P=0.0010)$. No

170

such stage-dependent 25(OH)D variations were seen in female COVID-19 patients.

171

172 Analysis of possible confounders by vitamin D-impacted comorbidities The higher rates of vitamin D

173 deficiency in COVID-19 patients might reflect a causal relation or be no more than a marker of poor

174 general health or nutritional status predisposing to severe COVID-19. To identify possible

175 confounders, we compared the prevalence of known vitamin D-impacted comorbidities such as 
medRxiv preprint doi: https://doi.org/10.1101/2020.05.01.20079376; this version posted May 19, 2020. The copyright holder for this preprint (which was not certified by peer review) is the author/funder, who has granted medRxiv a license to display the preprint in perpetuity.

It is made available under a CC-BY-NC-ND 4.0 International license .

176 chronic obstructive lung disease ${ }^{15,16}$, coronary artery disease and diabetes, in male versus female

177 and in vitamin D-deficient versus -replete COVID-19 patients. Prevalence of chronic lung disease,

178 coronary artery disease and diabetes in all COVID-19 patients were $15.1 \%, 59.1 \%$ and $14.0 \%$,

179 respectively, with no differences across COVID-19 disease stages (Table 2). The high prevalence of

180 coronary artery disease in COVID-19 patients was strongly correlated to patients' age $\left(r_{s}=0.655,95 \%\right.$

$181 \mathrm{Cl} 0.565-0.730, \mathrm{P}<0.0001)$. Male COVID-19 patients showed similar prevalence of diabetes and

182 coronary artery disease and a tendency towards more chronic lung diseases, that attained

183 significance only in male COVID-19 stage 1 patients. The latter difference was, however, not related

184 to differences in vitamin D status: male and female COVID-19 patients with normal (25(OH)D $\geq 20$

$185 \mathrm{ng} / \mathrm{mL}$ ) or deficient vitamin $\mathrm{D}$ status showed comparable prevalence of chronic lung disease,

186 coronary artery disease and diabetes (Table 3 ), indicating that the correlation between vitamin D

187 deficiency and the risk for severe COVID-19 was not confounded by any of these comorbidities.

188

189

190

191 This study is one of several rapidly emerging reports that correlate vitamin D deficiency to the risk for

192 severe presentations of COVID-19 lung disease. It is compatible with a recent study that correlated

193 severe vitamin D deficiency in the Philippines's population with COVID-19 disease burden and poor

194 outcome ${ }^{9}$. Our study is the first to show that more profound vitamin D deficiency predisposes to

195 more advanced radiological stages as proxy for the severity of the inflammatory process of COVID-19

196 pneumonia. It also describes a remarkable sexual dimorphism, not directly explained by sex

197 differences in overall vitamin D status in our population. This study also highlights vitamin D

198 deficiency as a neglected health issue, even in a wealthy population with access to good nutrition

199 and healthcare: with exception of the very young, more than $40 \%$ of our control population have

$20025(\mathrm{OH}) \mathrm{D}$ levels below $20 \mathrm{ng} / \mathrm{mL}$, a widely used threshold for adequate bone health. It can be

201 assumed that these numbers are representative for the total Belgian population that showed much

202 higher all-cause excess mortality during the SARS-CoV-2 peak infection phase than neighboring 
medRxiv preprint doi: https://doi.org/10.1101/2020.05.01.20079376; this version posted May 19, 2020. The copyright holder for this preprint (which was not certified by peer review) is the author/funder, who has granted medRxiv a license to display the preprint in perpetuity.

It is made available under a CC-BY-NC-ND 4.0 International license .

203 countries according to the European Mortality Monitoring project ${ }^{17}$ despite largely sufficient

204 hospital and ICU capacity. Our data thus represent a first field validation of a recent global epidemiological analysis that clearly correlated the overall incidence and mortality of COVID-19 to geographical latitude, nations' nutritional status and the associated known impact on vitamin D deficiency as proposed causal factor ${ }^{13}$.

208

Vitamin D deficiency might be cause or consequence of severe COVID-19 lung disease. It might also be simply a surrogate marker for an underlying confounding comorbidity or general indicator of poor nutrition and ill health. Chronic obstructive pulmonary disease and asthma have been shown to alter $25(\mathrm{OH})$ metabolism or sequestration ${ }^{15,16}$ with lower increments in circulating $25(\mathrm{OH}) \mathrm{D}$ status after controlled repletion. Vitamin D deficiency has also been correlated ${ }^{18}$ to known COVID-19 risk factors such as hypertension and diabetes. Our analysis of comorbidities strongly argue against such confounding effect: vitamin D deficiency was strongly correlated to the risk of advanced COVID-19, specifically in males, but vitamin D deficient COVID-19 patients did not show higher prevalence of known vitamin D-impacted diseases such as diabetes, coronary artery disease and chronic lung

217 disease. Another possible confounder is increased catabolism of circulating 25(OH)D in COVID-19 patients, attributed to extrarenal CYP27B1 activity and VDR expressed by the expanded repertoire of immune cells. In a USA population survey, subjects with CRP>5 mg/L showed $1.6 \mathrm{ng} / \mathrm{L}$ lower median $25(\mathrm{OH}) \mathrm{D}^{20}$. However, the stable $25(\mathrm{OH}) \mathrm{D}$ levels in female COVID-19 patients across all stages of the disease argue against such effect. Combined, our data thus support a causal role of vitamin D deficiency, in line with a recent modeling study using causal interference analysis of global COVID-19 incidence and mortality data ${ }^{13}$.

224 A substantial body of evidence explains a causal pathophysiological role of vitamin D in the severity 225 of respiratory viral infections. The immunological response to SARS-CoV-2 shows many similarities to 226 the response to SARS-CoV ${ }^{21}:$ in individuals with delayed type I/III interferon response and delayed 227 viral clearance, progressive recruitment of neutrophils and pro-inflammatory Th1/M1-polarized 228 immune cells contribute to endothelial and alveolar cell death and in some patients trigger a 
medRxiv preprint doi: https://doi.org/10.1101/2020.05.01.20079376; this version posted May 19, 2020. The copyright holder for this preprint (which was not certified by peer review) is the author/funder, who has granted medRxiv a license to display the preprint in perpetuity.

It is made available under a CC-BY-NC-ND 4.0 International license .

229 cytokine storm ${ }^{1}$ that enhances diffuse alveolar damage. Severe COVID-19 can thus be

230 conceptualized as an unbalance between pro-inflammatory type I immune response required for

231 viral clearance and tolerogenic type II response required for repair ${ }^{1,2,21}$. Vitamin $\mathrm{D}$ modulates the

232 immunological response to respiratory viruses at various phases: in the early phase of infection it

233 limits viral entry and replication by boosting cathelicidins/defensins expression in respiratory

epithelia ${ }^{5}$. Later on it exerts a tolerogenic effect by directly mediating IL-4/IL-13-dependent

polarization towards M2-macrophages and Th2 $\mathrm{CD} 4 \mathrm{~T}_{\text {cells }}{ }^{6}$. The mammalian immune system shows

conserved estrogen/androgen-dependent sexual dimorphism ${ }^{22}$. SARS-CoV-infected female mice

237

show lower viral replication, lower recruitment of inflammatory monocytes and neutrophils to the

238

lungs and less alveolar and endothelial cell death ${ }^{23}$. If vitamin D deficiency favors a pro-inflammatory

239

balance, the higher rates of vitamin D deficiency in male humans might thus act in concert with

estrogen/androgen-dependent immune differences and contribute to higher incidence and severity

241

in male COVID-19 patients.

242 Several randomized controlled interventional trials with vitamin D supplementation for bone health

243 or to reduce mortality in cardiovascular disease and cancer gave mixed or negative results, entailing

244 a sense of indifference from the medical community towards the value of vitamin D monitoring and

245 supplementation. An overlooked issue, however, was that many of those interventional trials

246 showed inappropriate design by targeting populations with no prior vitamin D deficiency, and were

247 not guided by actual $25(\mathrm{OH}) \mathrm{D}$ measurements ${ }^{24}$. A prior meta-analysis indicated that vitamin $\mathrm{D}$

248 supplementation reduces the incidence and severity of acute respiratory infections but only in those

249 patients with a deficient vitamin D level at the start as measured by $25(\mathrm{OH}) \mathrm{D}^{25}$.

250 In conclusion, our study shows a strong correlation between vitamin D deficiency and severe COVID-

25119 lung disease that is not explained by confounding comorbidities. In light of the established

252 immunological functions of vitamin $\mathrm{D}$, it is compatible with a causal role of vitamin D deficiency that

253 can explain variations in disease burden of COVID-19 across geographies, skin pigment types

254 (African/Latino), body mass (obese), socioeconomic status (poor) and lifestyle (institutionalized 
medRxiv preprint doi: https://doi.org/10.1101/2020.05.01.20079376; this version posted May 19, 2020. The copyright holder for this preprint

(which was not certified by peer review) is the author/funder, who has granted medRxiv a license to display the preprint in perpetuity.

It is made available under a CC-BY-NC-ND 4.0 International license.

255 people). Given the global prevalence of vitamin D deficiency, our data thus argue for vitamin D

256 supplementation as inexpensive, safe and readily available mitigation of the syndemic convergence

257 of two pandemics.

258 Competing interest and funding declaration

259 The authors declare no conflict of interest. The authors received no funding for this study.

260

261 Contributor and guarantor information

262 D.D.S., K.D.S and G.M. were responsible for planning and design of the study. Statistical analysis was

263 done by D.D.S. P.H. was responsible for laboratory analyses. S.G. and K.D.S. were responsible for CT

264 and structured reporting of radiological data. All authors contributed to the manuscript preparation,

265 read and approved it. G.M. was responsible for preparing the manuscript and is guarantor of the

266 study. The guarantor affirms that the manuscript is an honest, accurate, and transparent account of

267 the study being reported; that no important aspects of the study have been omitted; and that any

268 discrepancies from the study as planned (and, if relevant, registered) have been explained. The

269 authors declare that they will share anonymized source data of this study upon written request to

270 the guarantor.

271

272 
medRxiv preprint doi: https://doi.org/10.1101/2020.05.01.20079376; this version posted May 19, 2020. The copyright holder for this preprint (which was not certified by peer review) is the author/funder, who has granted medRxiv a license to display the preprint in perpetuity.

1. Chen G, Wu D, Guo W, et al. Clinical and immunological features of severe and moderate coronavirus disease 2019. J Clin Invest. 2020.

2. Mehta P, McAuley DF, Brown M, et al. COVID-19: consider cytokine storm syndromes and immunosuppression. Lancet. 2020;395(10229):1033-1034.

3. Chirumbolo S, Bjorklund G, Sboarina A, Vella A. The Role of Vitamin D in the Immune System as a Pro-survival Molecule. Clin Ther. 2017;39(5):894-916.

4. Cantorna MT, Yu S, Bruce D. The paradoxical effects of vitamin D on type 1 mediated immunity. Mol Aspects Med. 2008;29(6):369-375.

5. Liu PT, Stenger S, Li H, et al. Toll-like receptor triggering of a vitamin D-mediated human antimicrobial response. Science. 2006;311(5768):1770-1773.

6. Cantorna MT. Vitamin D and Lung Infection. Infect Immun. 2016;84(11):3094-3096.

7. Zdrenghea MT, Makrinioti H, Bagacean C, Bush A, Johnston SL, Stanciu LA. Vitamin D modulation of innate immune responses to respiratory viral infections. Rev Med Virol. 2017;27(1).

8. Greiller $\mathrm{CL}$, Martineau AR. Modulation of the immune response to respiratory viruses by vitamin D. Nutrients. 2015;7(6):4240-4270.

9. Alipio N. Vitamin D Supplementation Could Possibly Improve Clinical Outcomes of Patients Infected with Coronavirus-2019 (COVID-2019. Preprint available at SSRN: https://ssrncom/abstract=3571484. 2020.

10. Hilger J, Friedel A, Herr R, et al. A systematic review of vitamin D status in populations world wide. Br J Nutr. 2014;111(1):23-45.

11. Khunti KP, M. Is ethnicity linked to incidence or outcomes of covid-19? BMJ (369).

12. Alipio N. Vitamin D Supplementation Could Possibly Improve Clinical Outcomes of Patients Infected with Coronavirus-2019 (COVID-19) (April 9, 2020). Preprint available at SSRN: http://dxdoiorg/102139/ssrn3571484.

13. Davies G, Garami AR, Byers J. Evidence Supports a Causal Model for Vitamin D in COVID-19 Outcomes. medRxiv 2020050120087965; doi: https://doiorg/101101/2020050120087965.

14. Bernheim A, Mei X, Huang M, et al. Chest CT Findings in Coronavirus Disease-19 (COVID-19): Relationship to Duration of Infection. Radiology. 2020:200463.

15. Jolliffe DA, Stefanidis C, Wang Z, et al. Vitamin D Metabolism is Dysregulated in Asthma and Chronic Obstructive Pulmonary Disease. American journal of respiratory and critical care medicine. 2020.

16. Hiemstra PS, de Jongh RT. Vitamin D Deficiency in Asthma and Chronic Obstructive Pulmonary Disease: A Chicken or Egg Story. American journal of respiratory and critical care medicine. 2020.

17. Kanieff M, Rago G, Minelli G, et al. The potential for a concerted system for the rapid monitoring of excess mortality throughout Europe. Euro surveillance : bulletin Europeen sur les maladies transmissibles = European communicable disease bulletin . 2010;15(43).

18. Gouni-Berthold I, Berthold HK. Vitamin D and vascular disease. Current vascular pharmacology. 2020. 
medRxiv preprint doi: https://doi.org/10.1101/2020.05.01.20079376; this version posted May 19, 2020. The copyright holder for this preprint

(which was not certified by peer review) is the author/funder, who has granted medRxiv a license to display the preprint in perpetuity.

It is made available under a CC-BY-NC-ND 4.0 International license .

317 19. Mondul AM, Weinstein SJ, Layne TM, Albanes D. Vitamin D and Cancer Risk and Mortality: State of the Science, Gaps, and Challenges. Epidemiologic reviews.

319 2017;39(1):28-48.

320

20. Haynes BM, Pfeiffer CM, Sternberg MR, Schleicher RL. Selected physiologic variables are weakly to moderately associated with 29 biomarkers of diet and nutrition, NHANES 2003-2006. J Nutr. 2013;143(6):1001S-1010S.

21. Channappanavar R, Perlman S. Pathogenic human coronavirus infections: causes and consequences of cytokine storm and immunopathology. Semin Immunopathol. 2017;39(5):529-539.

22. Trigunaite A, Dimo J, Jorgensen TN. Suppressive effects of androgens on the immune system. Cell Immunol. 2015;294(2):87-94.

23. Channappanavar R, Fett C, Mack M, Ten Eyck PP, Meyerholz DK, Perlman S. SexBased Differences in Susceptibility to Severe Acute Respiratory Syndrome Coronavirus Infection. J Immunol. 2017;198(10):4046-4053.

24. Grant WB, Boucher BJ, Bhattoa HP, Lahore H. Why vitamin D clinical trials should be based on 25-hydroxyvitamin D concentrations. J Steroid Biochem Mol Biol. 2018;177:266-269.

25. Martineau AR, Jolliffe DA, Hooper RL, et al. Vitamin D supplementation to prevent acute respiratory tract infections: systematic review and meta-analysis of individual participant data. BMJ. 2017;356:i6583. 
medRxiv preprint doi: https://doi.org/10.1101/2020.05.01.20079376; this version posted May 19, 2020. The copyright holder for this preprint (which was not certified by peer review) is the author/funder, who has granted medRxiv a license to display the preprint in perpetuity.

It is made available under a CC-BY-NC-ND 4.0 International license .

341

342

343

344

345

346

347

348

349

350

351

352

353

354

355

356

357

358

359

360

361

362

363

364

365

366

Table legends

Table 1: Sex, age and seasonal variations in $25(\mathrm{OH})$ levels in the general population as derived from 25(OH)D measurements in 16274 unselected, consecutive and unique diseased control samples. The table lists for the number (percentage) of patients for the indicated groups, median (IQR) age (years), median (IQR) 25(OH)D level (ng/mL) and percentage vitamin D deficiency. Data (not normally distributed) are expressed as medians (25th-75th percentiles), and the Mann-Whitney test was used to test statistical difference between groups. Proportions for categorical variables were compared using chi-squared test. Upper case letters indicate relevant statistical differences detailed in the footnote.

Table 2: Demographic and comorbidity characteristics of diseased controls and COVID-19 patients and $25(\mathrm{OH})$ levels stratified by sex and radiological COVID-19 disease stage. + Indicates differences with diseased controls for which $\mathrm{P}$ values less than .05 were considered statistically significant. $¥$ Indicates differences with CT Stage 1 COVID-19 patients for which $\mathrm{P}$ values less than .05 were considered statistically significant. $\S$ Indicates differences of male versus female comorbidity prevalence for which $\mathrm{P}$ values less than .05 were considered statistically significant. Data (not normally distributed) are expressed as medians (25th-75th percentiles), and the Mann-Whitney test was used to test statistical difference between groups. Proportions for categorical variables were compared using chi-squared test. Exact P values listed in Supplementary information.

Table 3: Prevalence of comorbidities within COVID-19 patients stratified for sex and vitamin D deficiency status. Prevalence of the indicated vitamin D-impacted comorbidities are listed for all COVID-19 patients and grouped per sex (absolute number and percentage per subgroup) and compared between patients with or without vitamin D deficiency $(25(\mathrm{OH}) \mathrm{D}<20 \mathrm{ng} / \mathrm{mL})$. P values calculated by chi-squared testing indicate statistical differences between prevalence of the indicated 
medRxiv preprint doi: https://doi.org/10.1101/2020.05.01.20079376; this version posted May 19, 2020. The copyright holder for this preprint (which was not certified by peer review) is the author/funder, who has granted medRxiv a license to display the preprint in perpetuity.

$$
\text { It is made available under a CC-BY-NC-ND } 4.0 \text { International license. }
$$

367 comorbidity between all, female or male vitamin D deficient versus sufficient COVID-19 patients. ${ }^{\dagger}$

368 Indicates no statistical differences between males and females for the indicated comorbidity.

369

370 
medRxiv preprint doi: https://doi.org/10.1101/2020.05.01.20079376; this version posted May 19, 2020. The copyright holder for this preprint (which was not certified by peer review) is the author/funder, who has granted medRxiv a license to display the preprint in perpetuity.

It is made available under a CC-BY-NC-ND 4.0 International license .

Table 1: Table 1: Sex, age and seasonal variations in $25(\mathrm{OH})$ levels in the general population

\begin{tabular}{|c|c|c|c|c|}
\hline Patient group & n (\%) & $\begin{array}{l}\text { Age, } \\
\text { Median (IQR), y }\end{array}$ & $\begin{array}{l}\text { 25-OH-Vit D, Median } \\
\text { (IQR), ng/mL }\end{array}$ & $\begin{array}{l}25 \text {-OH-Vit D } \\
<20 \mathrm{ng} / \mathrm{mL} \text {, } \\
\mathrm{n}(\%)\end{array}$ \\
\hline \multicolumn{5}{|l|}{ Gender distribution } \\
\hline All & $16274(100)$ & $64.2(39.8-81.3)$ & $23.3(15.3-32.4)$ & 6491 (39.9) \\
\hline Female & $10045(61.7)$ & $63.3(37.4-82.0)$ & $23.7(15.6-33.1)$ & $3875(38.6)$ \\
\hline Male & $6229(38.3)$ & $65.2(44.5-80.3)$ & $22.3(14.9-31.3)^{a}$ & $2616(42.0)^{b}$ \\
\hline \multicolumn{5}{|c|}{ Age (year) distribution } \\
\hline \multicolumn{5}{|l|}{ All } \\
\hline$\leq 1$ & $113(0.7)$ & $0.7(0.3-0.8)$ & $44.4(37.3-55.1)$ & $6(5.3)$ \\
\hline $1-10$ & $761(4.7)$ & $5.0(2.9-7.3)$ & $32.7(26.0-42.0)$ & $83(10.9)$ \\
\hline $10-18$ & $399(2.5)$ & $13.1(11.5-15.3)$ & $23.9(17.4-30.0)$ & $130(32.6)$ \\
\hline $18-30$ & $1410(8.7)$ & $25.8(22.6-27.9)$ & $22.2(15.5-30.0)^{c, d}$ & $600(42.6)^{e, f}$ \\
\hline $30-50$ & $2842(17.5)$ & $40.1(34.9-45.5)$ & $22.5(15.7-30.6)^{c, d}$ & $1171(41.2)^{\mathrm{e}}$ \\
\hline $50-70$ & $3727(22.9)$ & $60.1(55.4-65.1)$ & $23.4(15.6-32.6)^{c}$ & $1467(39.4)^{e}$ \\
\hline$>70$ & $7022(43.1)$ & $82.9(77.5-87.7)$ & $22.3(13.9-31.9)^{c, d}$ & $3034(43.2)^{e, f}$ \\
\hline \multicolumn{5}{|l|}{ Female } \\
\hline$\leq 1$ & $49(0.5)$ & $0.7(0.4-0.8)$ & $44.8(38.8-54.6)$ & $4(8.2)$ \\
\hline $1-10$ & $360(3.6)$ & $5.5(3.2-7.3)$ & $32.9(25.5-41.7)$ & $33(9.2)$ \\
\hline $10-18$ & $240(2.4)$ & $13.6(11.5-15.5)$ & $23.3(17.0-29.9)^{g}$ & $83(34.6)^{i}$ \\
\hline $18-30$ & $1088(10.8)$ & $26.2(23.1-28.0)$ & $22.4(15.6-30.1)^{\mathrm{g}, \mathrm{h}}$ & $455(41.8)^{\mathrm{i}, \mathrm{j}}$ \\
\hline $30-50$ & $1862(18.5)$ & $39.1(34.3-44.6)$ & $22.9(15.9-31.6)^{g, h}$ & $737(39.6)^{i}$ \\
\hline $50-70$ & $2104(20.9)$ & $59.7(55.2-64.8)$ & $24.7(16.5-34.2)^{\mathrm{g}}$ & $766(36.4)^{i, j}$ \\
\hline$>70$ & $4342(43.2)$ & $83.6(78.2-88.1)$ & $23.1(14.0-32.9)^{\mathrm{g}, \mathrm{h}}$ & $1797(41.4)^{i}$ \\
\hline \multicolumn{5}{|l|}{ Male } \\
\hline$\leq 1$ & $64(1.0)$ & $0.6(0.3-0.8)$ & $44.3(37.1-55.7)$ & $2(3.1)$ \\
\hline $1-10$ & $401(6.4)$ & $4.7(2.6-7.3)$ & $32.1(26.3-42.0)$ & $50(12.5)$ \\
\hline $10-18$ & $159(2.6)$ & $12.8(11.4-14.9)$ & $24.5(18.7-31.1)$ & $47(29.6)$ \\
\hline $18-30$ & $322(5.2)$ & $24.4(21.2-27.4)$ & $21.6(14.9-29.1)^{k}$ & $145(45.0)^{m}$ \\
\hline $30-50$ & $980(15.7)$ & $41.7(36.4-46.2)$ & $21.8(15.5-29.3)^{k, l}$ & $434(44.3)^{m, n}$ \\
\hline $50-70$ & $1623(26.1)$ & $60.7(55.6-65.5)$ & $21.9(14.4-30.7)^{k, l}$ & $701(43.2)^{m, n}$ \\
\hline$>70$ & $2680(43.0)$ & $81.9(76.5-86.7)$ & $21.2(13.8-30.1)^{k, l}$ & $1237(46.2)^{m, n}$ \\
\hline \multicolumn{5}{|c|}{ Seasonal distribution } \\
\hline \multicolumn{5}{|l|}{ Winter } \\
\hline All & $3889(100)$ & $62.5(37.7-81.4)$ & $21.8(14.3-31.4)^{\circ}$ & $1740(44.7)^{q}$ \\
\hline Female & $2448(62.9)$ & $62.5(36.1-81.3)$ & $22.6(14.5-32.4)^{\circ}$ & $1040(42.5)^{\mathrm{q}}$ \\
\hline Male & $1441(37.1)$ & $62.8(40.9-79.5)$ & $20.4(14.1-29.8)^{o, p}$ & $700(48.6)^{q, r}$ \\
\hline \multicolumn{5}{|l|}{ Spring } \\
\hline All & $4277(100)$ & $65.8(40.5-81.6)$ & $22.2(14.4-31.0)^{\circ}$ & $1832(42.8)^{\mathrm{q}}$ \\
\hline Female & $2563(59.9)$ & $64.2(37.3-82.0)$ & $22.4(14.8-31.6)^{\circ}$ & $1075(41.9)^{\mathrm{q}}$ \\
\hline Male & $1714(40.1)$ & $67.5(46.3-81.0)$ & $21.8(14.0-30.3)^{o, p}$ & $757(44.2)^{q}$ \\
\hline \multicolumn{5}{|l|}{ Summer } \\
\hline All & $3619(100)$ & $63.3(40.6-81.6)$ & $25.7(17.0-35.0)$ & $1202(33.2)$ \\
\hline Female & $2296(63.4)$ & $63.6(38.8-82.5)$ & $25.8(17.2-35.4)$ & $748(32.6)$ \\
\hline Male & $1323(36.6)$ & $62.9(43.3-80.1)$ & $25.6(16.7-34.2)$ & $454(34.3)$ \\
\hline \multicolumn{5}{|l|}{ Fall } \\
\hline All & $4489(100)$ & $64.7(40.1-80.9)$ & $23.6(15.9-32.6)^{\circ}$ & $1717(38.3)^{\mathrm{q}}$ \\
\hline
\end{tabular}


medRxiv preprint doi: https://doi.org/10.1101/2020.05.01.20079376; this version posted May 19, 2020. The copyright holder for this preprint

(which was not certified by peer review) is the author/funder, who has granted medRxiv a license to display the preprint in perpetuity.

It is made available under a CC-BY-NC-ND 4.0 International license .

$\begin{array}{lllll}\text { Female } & 2738(61.0) & 63.1(37.4-81.3) & 24.2(16.1-33.3)^{\circ} & 1012(37.0)^{\mathrm{q}} \\ \text { Male } & 1751(39.0) & 66.3(45.7-80.3) & 23.0(15.6-31.3)^{\mathrm{o}, \mathrm{p}} & 705(40.3)^{\mathrm{q}, \mathrm{r}}\end{array}$

a $25-\mathrm{OH}$ Vitamin $\mathrm{D}$ levels were significantly lower $(P<.0001)$ in men than in women.

b Prevalence of $25-\mathrm{OH}$ Vitamin D deficiency was significantly higher $(P<.0001)$ in men than in women.

c $25-\mathrm{OH}$ Vitamin D levels were significantly lower $(P<.05)$ for all individual age groups $>18$ years as compared with those aged $\leq 18$ years.

d For all individuals aged $>18$ years, subgroup 50-70 years showed significantly higher $(P<0.05)$ as compared with the other age groups.

e All age groups $>18$ years showed significantly higher $(P<.05)$ prevalence of $25-\mathrm{OH}$ Vitamin D deficiency as compared with the individual age groups $\leq 18$ years.

$f$ For individuals aged $>18$ years, subgroup 50-70 years showed significantly lower $(P<0.05)$ prevalence of $25-\mathrm{OH}$ Vitamin D deficiency than the age groups $18-30$ years and $>70$ years.

g $25-\mathrm{OH}$ Vitamin D levels were significantly lower $(P<.0001)$ for female age groups $>10$ years as compared with those aged $\leq 10$ years.

h For women aged $>18$ years, subgroup 50-70 years showed significantly higher $(P<0.001) 25-\mathrm{OH}$ Vitamin $\mathrm{D}$ levels as compared with the other age groups.

i All female age groups $>10$ years showed significantly higher $(P<.001)$ prevalence of $25-\mathrm{OH}$ Vitamin $\mathrm{D}$ deficiency as compared with the individual age groups $\leq 10$ years.

j For women aged $>10$ years, subgroups 10-18 years and 50-70 years showed significantly lower $(P<.05)$ prevalence of 25-OH Vitamin D deficiency as compared with the other age groups.

k $25-\mathrm{OH}$ Vitamin D levels were significantly lower $(\mathrm{P}<.001)$ for male age groups $>18$ years as compared with those aged $\leq 18$ years. Male age groups $>18$ years did not show significant mutual differences.

I $25-\mathrm{OH}$ Vitamin $\mathrm{D}$ levels were significantly lower $(\mathrm{P}<.001)$ for male age groups $>30$ years as compared with female age groups $>30$ years.

$m$ All male age groups $>18$ years showed sign ificantly higher $(P<.001)$ prevalence of $25-\mathrm{OH}$ Vitamin $D$ deficiency as compared with the individual age groups $\leq 18$ years. Male age groups $>18$ years did not show significant mutual differences.

n Male age groups 30-50 years, 50-70 years and $>70$ years showed significantly higher prevalence of 25-OH Vitamin D deficiency as compared with the female age groups (respectively $P<.05, P=.0001$ and $P<.0001$ ).

- For all patients and gender subgroups, 25-OH Vitamin D levels in winter and spring did not differ significantly. Winterspring $25-\mathrm{OH}$ Vitamin D levels were significantly lower as compared with summer $(P<.0001)$ and fall $(P<.05)$. 25-OH Vitamin D levels were significantly lower $(P<.0001)$ in fall than those measured in summer.

$\mathrm{p}$ In all seasons, except for the summer, males have significantly lower $25-\mathrm{OH}$ Vitamin D levels $(P<.05)$ as compared with women.

q For all patients and female patients, prevalence of 25-OH Vitamin D deficiency in winter versus spring did not differ significantly. In contrast, male patients showed significantly higher $(P<.05)$ prevalence of $25-\mathrm{OH}$ Vitamin D deficiency in winter versus spring. For all patients and gender subgroups, winter-spring prevalence of 25-OH Vitamin D deficiency were sign ificantly higher as compared with summer $(P<.001)$ and fall $(P<.05) .25-\mathrm{OH}$ Vitamin $\mathrm{D}$ deficiency was significantly more prevalent $(P<.001)$ in fall than in summer.

$r$ In winter and fall, prevalence of $5-\mathrm{OH}$ Vitamin $\mathrm{D}$ deficiency was significantly higher $(\mathrm{P}<.05)$ in men than in women. 
medRxiv preprint doi: https://doi.org/10.1101/2020.05.01.20079376; this version posted May 19, 2020. The copyright holder for this preprint (which was not certified by peer review) is the author/funder, who has granted medRxiv a license to display the preprint in perpetuity.

It is made available under a CC-BY-NC-ND 4.0 International license .

Table 2. Demographic and comorbidity characteristics of diseased controls and COVID-19 patients and 25(OH) levels stratified by sex and radiological COVID-19 disease stage

\begin{tabular}{|c|c|c|c|c|c|c|}
\hline $\begin{array}{l}\text { Patient } \\
\text { group }\end{array}$ & Characteristic & $\begin{array}{l}\text { Diseased } \\
\text { Controls }\end{array}$ & $\begin{array}{l}\text { COVID-19 } \\
\text { (all) }\end{array}$ & $\begin{array}{l}\text { COVID-19 } \\
\text { (CT Stage 1) }\end{array}$ & $\begin{array}{l}\text { COVID-19 } \\
\text { (CT Stage 2) }\end{array}$ & $\begin{array}{l}\text { COVID-19 } \\
\text { (CT Stage 3) }\end{array}$ \\
\hline \multirow[t]{13}{*}{ All patients } & $\mathrm{n}$ & 2717 & 186 & 46 & 55 & 85 \\
\hline & Age, median (IQR), y & $68(49-82)$ & $69(52-80)$ & $74(53-82)$ & $71(60-78)$ & $63(50-80)$ \\
\hline & Sex & & & & & \\
\hline & Female, $\mathrm{n}(\%)$ & $1718(63.2)$ & $77(41.4)^{+}$ & $17(37.0)^{+}$ & $25(45.5)^{+}$ & $35(41.2)^{+}$ \\
\hline & Male, $n(\%)$ & $999(36.8)$ & $109(58.6)^{+}$ & $29(63.0)^{+}$ & $30(54.5)^{+}$ & $50(58.8)^{+}$ \\
\hline & Comorbidity & & & & & \\
\hline & $\begin{array}{l}\text { Chronic lung disease, } n(\%) \\
\text { Coronary artery disease, } n\end{array}$ & n.d. & $28(15.1)$ & $8(17.4)$ & $9(16.4)$ & $11(12.9)$ \\
\hline & $(\%)$ & n.d. & $110(59.1)$ & $32(69.6)$ & $32(58.2)$ & $46(54.1)$ \\
\hline & Diabetes, n (\%) & n.d. & $26(14.0)$ & $9(19.6)$ & $7(12.7)$ & $10(11.8)$ \\
\hline & 25-OH-Vitamin D & & & & & \\
\hline & Median (IOR), ng/mL & $21.5(13.9-20.8)$ & $18,6(12.6-25.3)^{+}$ & $19.7(16.2-30.8)$ & $17.6(12.0-26.0)^{+}$ & $\underset{\ddagger}{16.9}(12.6-23.8)^{+}$ \\
\hline & $\geq 20 \mathrm{ng} / \mathrm{mL}, \mathrm{n}(\%)$ & $1490(54.8)$ & $77(41.4)^{+}$ & $22(47.8)$ & $23(41.8)$ & $32(37.6)^{+}$ \\
\hline & $<20 \mathrm{ng} / \mathrm{mL}, \mathrm{n}(\%)$ & $1227(45.2)$ & $109(58.6)^{+}$ & $24(52.2)$ & $32(58.2)$ & $53(62.4)^{+}$ \\
\hline \multirow[t]{10}{*}{$\begin{array}{l}\text { Female } \\
\text { patients }\end{array}$} & $\mathrm{n}$ & 1718 & 77 & 17 & 25 & 35 \\
\hline & Age, median (IQR), y & $68(46-83)$ & $71(65-74)$ & $68(46-83)$ & $72(64-76)$ & $66(49-82)$ \\
\hline & Comorbidity & & & & & \\
\hline & $\begin{array}{l}\text { Chronic lung disease, } n(\%) \\
\text { Coronary artery disease, } n\end{array}$ & n.d. & $7(9.1)$ & $0(0.0)^{\S}$ & $3(12.0)$ & $4(11.4)$ \\
\hline & $(\%)$ & n.d. & $43(55.8)$ & $11(64.7)$ & $13(52.0)$ & $19(54.3)$ \\
\hline & Diabetes, n (\%) & n.d. & $11(14.3)$ & $4(23.5)$ & $4(16.0)$ & $3(8.6)$ \\
\hline & 25-OH-Vitamin D & & & & & \\
\hline & Median (IOR), ng/mL & $22,4(14.2-32.0)$ & $20.7(12.4-29.8)$ & $20.7(10.4-33.0)$ & $20.3(11.7-27.7)$ & $21.2(15.1-29.6)$ \\
\hline & $\geq 20 \mathrm{ng} / \mathrm{mL}, \mathrm{n}(\%)$ & $983(57.2)$ & $41(53.2)$ & 9 (52.9) & $13(52.0)$ & $19(54.3)$ \\
\hline & $<20 \mathrm{ng} / \mathrm{mL}, \mathrm{n}(\%)$ & $735(42.8)$ & $36(46.8)$ & $8(47.1)$ & $12(48.0)$ & $16(45.7)$ \\
\hline \multirow[t]{10}{*}{$\begin{array}{l}\text { Male } \\
\text { patients }\end{array}$} & $\mathrm{n}$ & 999 & 109 & 29 & 30 & 50 \\
\hline & Age, median (IQR), y & $69(53-81)$ & $68(53-79)$ & $74(58-81)$ & $71(59-78)$ & $59(52-77)$ \\
\hline & Comorbidity & & & & & \\
\hline & $\begin{array}{l}\text { Chronic lung disease, } \mathrm{n}(\%) \\
\text { Coronary artery disease, } \mathrm{n}\end{array}$ & n.d. & $21(19.3)$ & $8(27.6)^{\S}$ & $6(20.0)$ & $7(14.0)$ \\
\hline & $(\%)$ & n.d. & $67(61.5)$ & $21(72.4)$ & $19(63.3)$ & $27(54.0)$ \\
\hline & Diabetes, n (\%) & n.d. & $5(13.8)$ & $5(17.2)$ & $3(10.0)$ & $7(14.0)$ \\
\hline & 25-OH-Vitamin D & & & & & $16.0(12.0$ \\
\hline & Median (IQR), ng/mL & $20.3(13.7-28.4)$ & $17.6(12.7-24.0)^{+}$ & $19.4(18.2-29.8)$ & $16.5(12.1-24.0)^{\ddagger}$ & \\
\hline & $\geq 20 \mathrm{ng} / \mathrm{mL}, \mathrm{n}(\%)$ & $507(50.8)$ & $36(33.0)^{+}$ & $13(44.8)$ & $10(33.3)$ & $13(26.0)^{+}$ \\
\hline & $<20 \mathrm{ng} / \mathrm{mL}, \mathrm{n}(\%)$ & $492(49.2)$ & $73(67.0)^{+}$ & $16(55.2)$ & $20(66.7)$ & $37(74.0)^{+}$ \\
\hline
\end{tabular}

† Indicates differences with diseased controls for which $P$ values less than .05 were considered statistically significant.

$¥$ Indicates differences with CT Stage 1 COVID-19 patients for which P values less than .05 were considered statistically significant.

$\S$ Indicates differences of male vs female comorbidity prevalence for which P values less than 05 were considered statistically significant. 
medRxiv preprint doi: https://doi.org/10.1101/2020.05.01.20079376; this version posted May 19, 2020. The copyright holder for this preprint (which was not certified by peer review) is the author/funder, who has granted medRxiv a license to display the preprint in perpetuity.

It is made available under a CC-BY-NC-ND 4.0 International license.

372

Table 3. Prevalence of comorbidities within COVID-19 patients stratified for sex and vitamin D deficiency status.

\begin{tabular}{|c|c|c|c|c|}
\hline Patient group & Comorbidity & $\begin{array}{l}\text { 25-OH-vitamin D } \\
\geq 20 \mathrm{ng} / \mathrm{mL}\end{array}$ & $\begin{array}{l}\text { 25-OH-vitamin D } \\
<20 \mathrm{ng} / \mathrm{mL}\end{array}$ & $P$ \\
\hline \multirow[t]{4}{*}{ All patients $(n=186)$} & $\mathrm{n}$ & 77 & 109 & \\
\hline & Chronic lung disease, n (\%) & $13(16.9)$ & $15(13.8)$ & .7085 \\
\hline & $\begin{array}{l}\text { Coronary artery disease, } n \\
(\%)\end{array}$ & $48(62.3)$ & $62(56.9)$ & .5575 \\
\hline & Diabetes, n (\%) & $11(14.3)$ & $15(13.8)$ & .9063 \\
\hline \multirow[t]{4}{*}{ Female patients $(n=77)$} & $\mathrm{n}$ & 41 & 36 & \\
\hline & Chronic lung disease, n (\%) & $4(9.8)$ & $3(8.3)$ & .8660 \\
\hline & $\begin{array}{l}\text { Coronary artery disease, } n \\
(\%)\end{array}$ & $25(61.0)$ & $18(50.0)$ & .4594 \\
\hline & Diabetes, n (\%) & $7(17.1)$ & $4(11.1)$ & .6714 \\
\hline \multirow[t]{4}{*}{ Male patients $(n=109)$} & $\mathrm{n}$ & 36 & 73 & \\
\hline & Chronic lung disease, $\mathrm{n}(\%)$ & $9(25.0)^{+}$ & $12(16.4)^{+}$ & .4163 \\
\hline & $\begin{array}{l}\text { Coronary artery disease, } n \\
(\%)\end{array}$ & $23(63.9)^{+}$ & $44(60.3)^{+}$ & .8776 \\
\hline & Diabetes, n (\%) & $4(11.1)^{+}$ & $11(15.1)^{+}$ & .7838 \\
\hline
\end{tabular}

373

374 
medRxiv preprint doi: https://doi.org/10.1101/2020.05.01.20079376; this version posted May 19, 2020. The copyright holder for this preprint (which was not certified by peer review) is the author/funder, who has granted medRxiv a license to display the preprint in perpetuity.

It is made available under a CC-BY-NC-ND 4.0 International license .

Figure 1

376
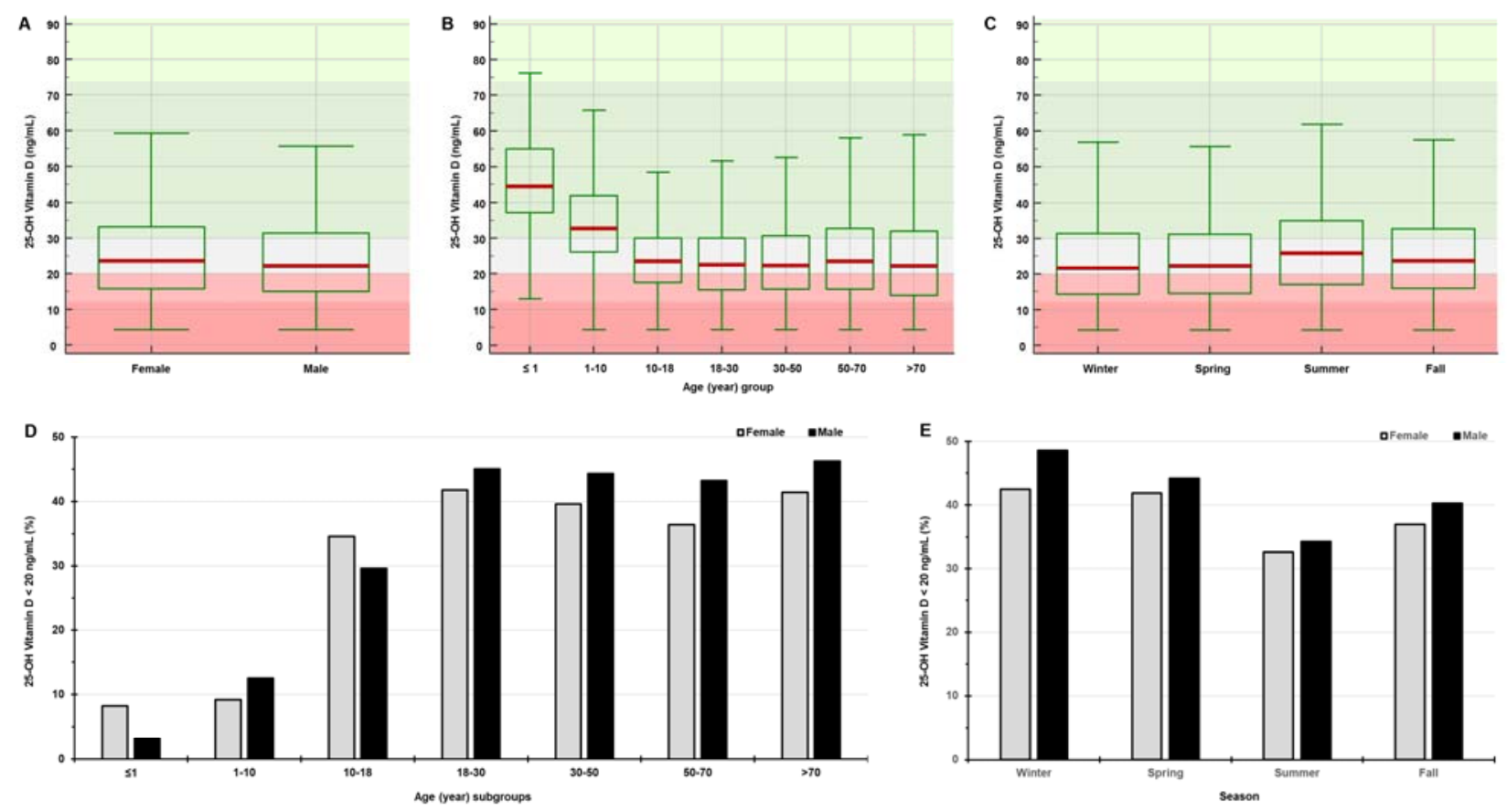

Figure 1: Prevalence and distribution of vitamin $D$ deficiency in the general population as derived from 25(OH)D measurements in 16274 unselected, consecutive and unique diseased control samples Box-and-Whisker plots show median (IQR) $25(\mathrm{OH}) \mathrm{D}$ levels $(\mathrm{ng} / \mathrm{mL}$ ) grouped by (A) sex, (B) the indicated age groups and (C) Northern hemisphere meteorological seasons. Background color in box plots indicates normal vitamin D status (green, $25(\mathrm{OH}) \mathrm{D}>30 \mathrm{ng} / \mathrm{mL}$ ), vitamin $\mathrm{D}$ deficiency (pale red, $25(\mathrm{OH}) \mathrm{D}<20 \mathrm{ng} / \mathrm{mL}$ ), severe vitamin D deficiency (darker red, $25(\mathrm{OH}) \mathrm{D}<12 \mathrm{ng} / \mathrm{mL}$ ) and a gray zone $(20 \mathrm{ng} / \mathrm{mL} \leq 25(\mathrm{OH}) \mathrm{D} \leq 30 \mathrm{ng} / \mathrm{mL})$. Lower panels indicate the percentage vitamin D deficiency $(25(\mathrm{OH}) \mathrm{D}<20 \mathrm{ng} / \mathrm{mL}$ ) in females (gray bars) and males (black bars) (D) in the indicated age groups (years) and (E) across seasons. Corresponding numbers per group, median (IQR) 25(OH)D, deficiency rates and relevant statistical differences are detailed in Table 1. 
medRxiv preprint doi: https://doi.org/10.1101/2020.05.01.20079376; this version posted May 19, 2020. The copyright holder for this preprint (which was not certified by peer review) is the author/funder, who has granted medRxiv a license to display the preprint in perpetuity.

A

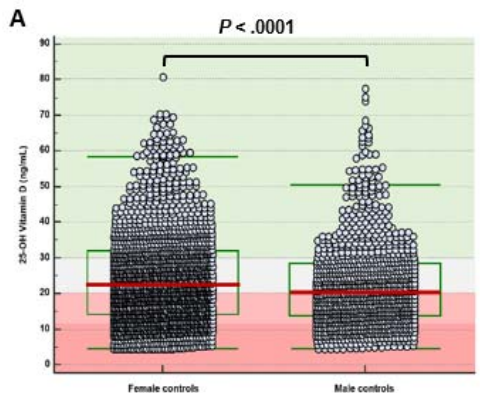

D

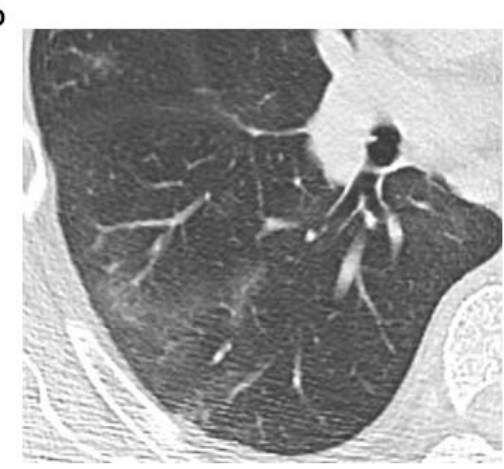

G

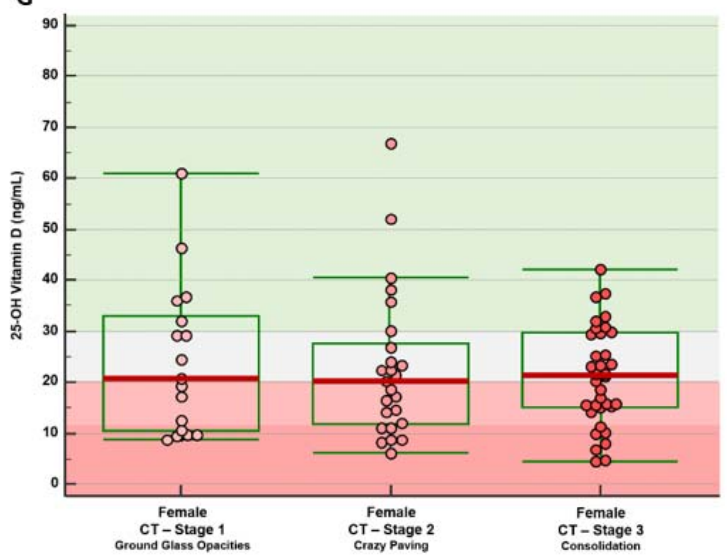

B

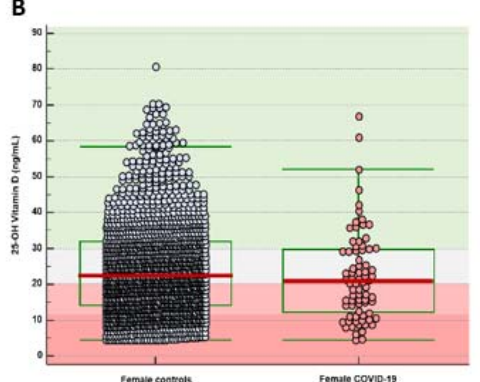

E

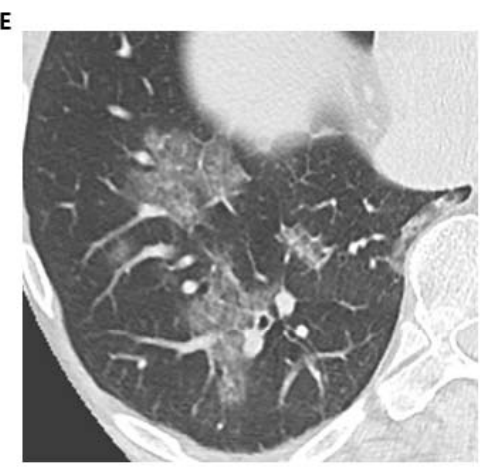

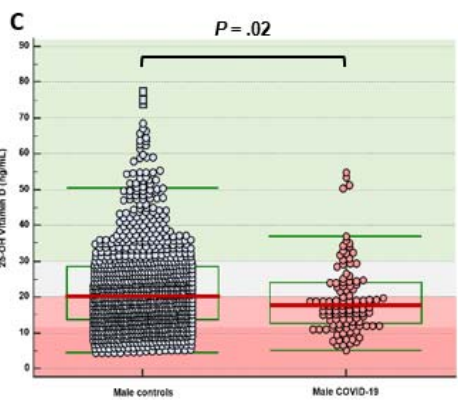

F

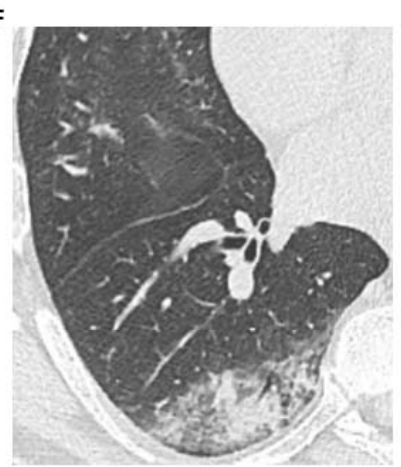

H

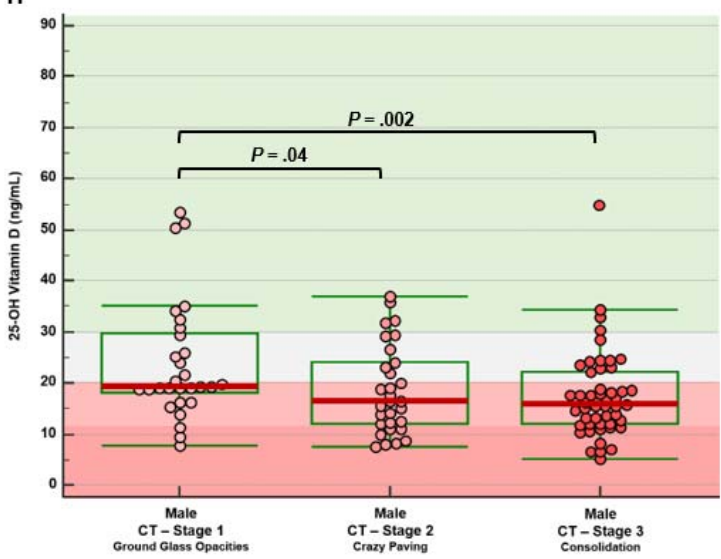

393
Figure 2: $25(\mathrm{OH}) \mathrm{D}$ levels in male and female COVID-19 patients and age/season-matched controls and stratification by COVID-19 disease stage Panels A-C: Box-and-Whisker plots showing median (red line) serum $25(\mathrm{OH})$ levels and interquartile ranges (green box) in (A) season- and age-matched female $(n=1718)$ versus male $(n=999)$ diseased controls; (B) female COVID-19 patients on admission $(n=77)$ versus female controls; (C) male COVID-19 patients on admission $(n=109)$ versus male controls. Panels D-F: representative images of radiological stages of COVID-19 lung disease with predominantly (D) ground-glass opacities in early stage; (E) crazy paving patterns in progressive stage 2; and (F) consolidation in peak stage 3. Panel G-H: box-and-whisker plots of 25(OH)D in (G) female COVID-19 patients and (H) male COVID-19 patients grouped according to radiological stage. Background color in box plots indicates normal vitamin D status (green, 25(OH)D > $30 \mathrm{ng} / \mathrm{mL}$ ), vitamin $D$ deficiency (pale red, 25(OH)D $<20 \mathrm{ng} / \mathrm{mL}$ ), severe vitamin $D$ deficiency (darker red, $25(\mathrm{OH}) \mathrm{D}<12 \mathrm{ng} / \mathrm{mL}$ ) and a gray zone $(20 \mathrm{ng} / \mathrm{mL} \leq 25(\mathrm{OH}) \mathrm{D} \leq 30 \mathrm{ng} / \mathrm{mL})$. P values indicate statistical 
medRxiv preprint doi: https://doi.org/10.1101/2020.05.01.20079376; this version posted May 19, 2020. The copyright holder for this preprint (which was not certified by peer review) is the author/funder, who has granted medRxiv a license to display the preprint in perpetuity. It is made available under a CC-BY-NC-ND 4.0 International license.

407 differences between groups calculated by Mann-Whitney test. Exact P values listed in Supplementary 408 information. 